\title{
Simulation of the effects of diet on the contribution of rumen protozoa to degradation of fibre in the rumen
}

\author{
BY JAN DIJKSTRA ${ }^{1,2 *}$ AND SEERP TAMMINGA ${ }^{2}$ \\ ${ }^{1}$ Institute of Grassland and Environmental Research, North Wyke Research Station, Okehampton, \\ Devon EX20 $2 S B$ \\ ${ }^{2}$ Wageningen Agricultural University, Department of Animal Nutrition, Haagsteeg 4, 6708 PM \\ Wageningen, The Netherlands
}

(Received 28 April 1994 - Revised 9 February 1995-Accepted 10 March 1995)

\begin{abstract}
A previously described mathematical model, that simulates the metabolic activities of rumen bacteria and protozoa, was used to examine the contribution of protozoa to neutral-detergent fibre (NDF) degradation in the rumen of cattle. Comparisons between predicted and experimentally observed NDF degradation showed general agreement. Further simulations were performed with diets containing variable proportions of concentrate (between 0 and $1 \mathrm{~kg} / \mathrm{kg}$ diet DM) and at intake levels ranging between 5.3 and $21.0 \mathrm{~kg} \mathrm{DM} / \mathrm{d}$. The simulated protozoal contribution to NDF degradation was $17-21 \%$ at the lowest intake level. Except for the all-concentrate diets, raising the feed intake level reduced this contribution to 5-13\% at the highest intake level. The changes in contribution of protozoa to NDF degradation were related to variations in the fibrolytic bacteria: protozoa value and the NDF-degrading activities of protozoa predicted by the model. In simulations where dietary NDF levels were reduced and starch and sugar levels were increased independently, protozoal contribution to NDF degradation generally increased. These differences were reflected also in the generally increased protozoal contribution to NDF degradation predicted in response to a decreased roughage:concentrate value. The contribution of protozoa also generally declined in response to added $\mathbf{N}$. These changes in predicted protozoal contribution to NDF degradation resulting from dietary variations provided possible explanations for the differences in rumen NDF degradation observed when animals are defaunated.
\end{abstract}

Computer simulation: Mathematical model: Protozoa: Rumen: Fibre digestion

Forages, which generally contain large amounts of cell-wall carbohydrates, form the basis of a ruminant diet. The rumen is the major site of degradation of cell-wall carbohydrates (Van Soest, 1982). A mixed population of rumen micro-organisms, including bacteria, protozoa and fungi, are involved in fibre degradation. In contrast with the considerable knowledge on predominant rumen fibrolytic bacteria, the role of rumen protozoa in fibre degradation is still controversial (for reviews, see Williams, 1986; Jouany, 1989; Ushida et al. 1991), whereas the knowledge on rumen fungi is limited because of their relatively recent discovery (for review, see Trinci et al. 1994). The study of the contribution of protozoa to fibre degradation is severely hampered by the inability to cultivate protozoa routinely in vitro in the absence of growing bacteria. The use of defaunated animals could provide an alternative, but reported results are controversial (Ushida et al. 1991). The effect of defaunation of the rumen on in vivo or in vitro rumen fibre degradation varies between over $50 \%$ inhibition and $15 \%$ stimulation (for review, see Demeyer, 1989). Results of

\footnotetext{
* Present address: Institute of Grassland and Environmental Research, North Wyke Research Station, Okehampton, Devon EX20 2SB.
} 
biochemical, cultural and microscopic studies indicate that the contribution of protozoa depends on the complex interactions between protozoa, bacteria and dietary characteristics (for review, see Jouany, 1989). Thus, attempts to explain the non-systematic modifications resulting from removal of protozoa should include these relationships. An increased understanding of interactions between several components of a biological system needs an integrative approach, which presently is only possible through mathematical representation of the processes involved (Thornley \& Johnson, 1990).

The aim of the present study was to examine the roles of the rumen protozoa in fibre degradation on a wide range of dietary inputs, using a mathematical model of rumen fermentation (Dijkstra, 1994).

\section{MATERIALS AND METHODS \\ General model description}

A full description of the model, including the assumptions on protozoal and bacterial metabolism, and derivation of variable values, has been presented previously (Dijkstra et al. 1992; Dijkstra, 1994). The model is driven by continuous inputs of nutrients, calculated from the amount of feed fed and the chemical composition of the diet, including estimates of solubility, degradability and digestion turnover times of feed components, and by fractional outflow rates of fluid and solid phases as well as rumen fluid $\mathrm{pH}$. The model comprises nineteen state variables. These state variables relate to the carbohydrate entities (rumen degradable and undegradable fibre, starch and mono- or disaccharides derived from hydrolysis of fibre, starch and sugars), $\mathrm{N}$-containing entities (rumen degradable and undegradable protein and $\mathrm{NH}_{3}$ ), fatty acid-containing entities (lipid and volatile fatty acids) and microbial entities (amylolytic bacteria, fibrolytic bacteria and protozoa). The majority of the transaction kinetics were described using standard expressions from enzyme kinetics (Michaelis-Menten equations). The computer program was written in Advanced Continuous Simulation Language (Mitchell \& Gauthier, 1981) and the model was solved by integration of nineteen state variables with a fourth-order Runge-Kutta method (France \& Thornley, 1984).

\section{Representation of protozoal metabolism and fibre degradation}

A brief description of the representation of protozoal metabolism and fibre utilization by rumen bacteria and protozoa is given; full details can be found elsewhere (Dijkstra et al. 1992; Dijkstra, 1994). In view of substrate preferences shown by many bacterial species, in the model the amylolytic bacteria and fibrolytic bacteria have been represented separately. The first group utilized hexose derived from starch and sugars, the latter utilized hexose derived from fibre. Protozoa utilized fibre as well as starch and sugars. Although the metabolism of protozoal genera can differ, in the model the genera were not represented separately. Ideally, the number of microbial compartments to be included in the model (i.e. number of microbial groups or genera) should be based on the distinct differences in metabolism between groups, but is dependent also on the objectives of the model in relation to the general hierarchy and level of aggregation (Gill et al. 1989). Since the specific model objective was to examine the role of rumen protozoa in fibre degradation, without examining the role of individual protozoal genera, it was decided not to distinguish genera separately; the lack of experimental data on individual genera would severely hamper such a detailed representation.

The maximum rate of fibre utilization by protozoa was assumed to be lower than the maximum rate of starch or soluble sugar utilization, in view of the higher maximum 
fractional growth rates reported for species characterized by low cellulase (EC 3.2.1.4) and/or hemicellulase activities (for review, see Williams \& Coleman, 1988). The protozoal maintenance requirement was set at a value in line with the protozoal endogenous carbohydrate utilization in the absence of a substrate (Prins \& Van Hoven, 1977; Van Hoven \& Prins, 1977). The actual maximum rates of substrate uptake were then calculated from the protozoal maximum growth rates and maintenance rate, using the Pirt doublereciprocal equation of growth yield $v$. dilution rate (Pirt, 1965).

It was assumed that physical exclusion due to presence of starch within the protozoa reduced the uptake of insoluble material (fibre, starch, micro-organisms) (Coleman, 1975, 1992). Starch and sugars are the main precursors of protozoal starch (Coleman, 1992). Starch uptake is rapid when protozoal starch content is low, but starch uptake is reduced to low levels when protozoa are completely filled with starch (Coleman, 1986a). Similarly, the protozoal starch content is not increased above a certain level even if the soluble sugar concentration in the surrounding fluid is increased further (Van Hoven \& Prins, 1977). In comparison with the pattern of uptake of starch in relation to the degree of fill of protozoa, the bacteria are engulfed more slowly but progressively (Coleman, 1975). In view of these observations, a sigmoidal response function, giving a sharp switch-off characteristic at substrate levels supporting the maximal protozoal starch content, is appropriate for uptake of starch and sugars, whereas a weak sigmoidal response is required to represent the uptake of bacteria as influenced by the degree of starch fill of protozoa (Gill et al. 1989). It was assumed that amylolytic and cellulolytic bacteria are engulfed by protozoa in the proportion in which the bacteria are present. This assumption was based on experimental observations, which indicated that although selective engulfment of bacteria by some protozoal species might occur, no consistent pattern between protozoal species could be found (for review, see Coleman, 1989). In the absence of further data on uptake of particulate material the variables related to uptake of fibre by protozoa, as influenced by protozoal starch content, were assumed to be equal to the variables for uptake of bacteria. In the model, inhibition of microbial fibre degradation by low rumen fluid $\mathrm{pH}$ values was represented as follows. Fibre degradation by the fibrolytic bacteria was assumed to be sigmoidally inhibited at pH values lower than 6.3 (for details, see Dijkstra et al. 1992). Inhibition of protozoal fibre degradation was related to the amount of starch within the protozoa and the protozoal death rate. Diets rich in easily degradable carbohydrates, which are generally accompanied by low rumen-fluid $\mathrm{pH}$ values (Van Soest, 1982), supported high protozoal starch levels and consequently reduced fibre uptake rates, as explained previously. Increased lysis of protozoa on diets rich in easily degradable carbohydrates has been reported frequently (for review, see Williams \& Coleman, 1988) and this has been included in the model. The values for variables representing protozoal lysis were related to maximum protozoal growth rates and to observations that death rate is raised when availability of starch and sugars is increased (for review, see Williams \& Coleman, 1988), again necessitating a weak sigmoidal response representation.

\section{Simulated diets}

The simulations were conducted for dairy cows and were designed to study the effects of different intake levels, variations in the proportions of concentrate in the diet, and changes in dietary levels of neutral-detergent fibre (NDF), starch, sugars and $\mathrm{N}$ on protozoal contribution to degradation of NDF in the rumen. The input values were based on the results of Robinson et al. $(1986,1987)$. In this experiment, dairy cows (average body weight $583 \mathrm{~kg}$ ) were fed on diets of ryegrass hay-concentrate $(1: 2, \mathrm{w} / \mathrm{w})$ containing different proportions of starch, at intake levels of $5 \cdot 3,9 \cdot 2,13 \cdot 1,17 \cdot 1$ and $21 \cdot 0 \mathrm{~kg} \mathrm{DM} / \mathrm{d}$. Simulations were performed for the intermediate level of starch in the concentrate. The chemical 
Table 1. Chemical composition $(\mathrm{g} / \mathrm{kg} \mathrm{DM})$ of the hay and concentrate used in simulations (adopted from Robinson et al. 1986)

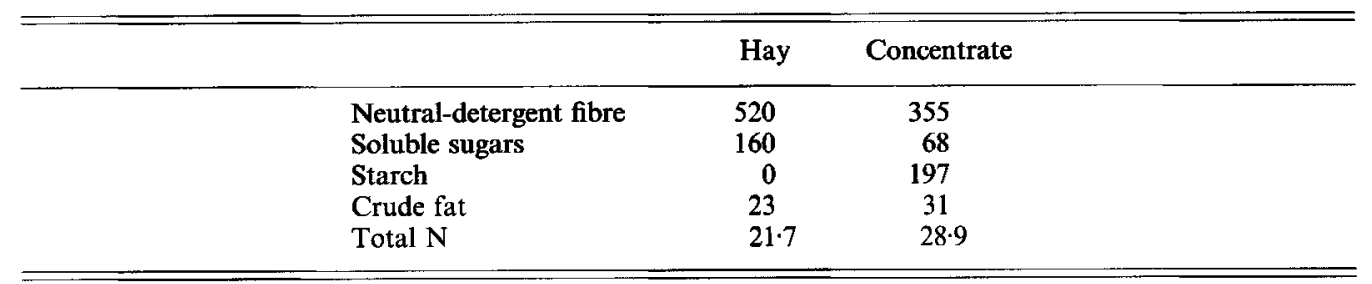

composition of the hay and the concentrate is given in Table 1. Estimates of soluble and undegradable fractions and digestion turnover times were calculated as described previously (Dijkstra et al. 1992). Fluid and solid passage rates, rumen volume and rumen fluid $\mathrm{pH}$ at the different intake levels were adopted from Robinson et al. $(1986,1987)$.

The effect of the roughage:concentrate ratio at several intake levels was investigated using the same hay and concentrate (Table 1), with proportions of concentrate in the diet set at $0,333,667$ and $1000 \mathrm{~g} / \mathrm{kg}$. Changes in fluid and solid passage rates were estimated according to the relative changes calculated using the regression equations reported in the review of Owens \& Goetsch (1986). For each intake level, pH values of the 0 and $333 \mathrm{~g}$ concentrate $/ \mathrm{kg}$ diets were assumed to be 0.2 and 0.1 units higher respectively, and that of the $1000 \mathrm{~g}$ concentrate $/ \mathrm{kg}$ diet to be 0.1 unit lower than the corresponding value for the $667 \mathrm{~g}$ concentrate $/ \mathrm{kg}$ diet reported by Robinson et al. (1987). Some justification for these assumptions on $\mathrm{pH}$ changes are the $\mathrm{pH}$ decrease (on average 0.2 to 0.3 units) on hay diets when the proportion of dietary concentrate increased from 0 to $800 \mathrm{~g} / \mathrm{kg}$ (Latham et al. 1971), and the values of mean and minimum $\mathrm{pH}$ reported by Bosch et al. (1992) on silagebased diets (mean and minimum $\mathrm{pH}$ decrease of 0.2 and 0.3 units respectively when dietary concentrate proportion increased from 60 to $360 \mathrm{~g} / \mathrm{kg}$, accompanied by an increase of DM intake from 13.3 to $17 \cdot 3 \mathrm{~kg} / \mathrm{d}$ ).

To assess the effect of the individual feed components, the amount of NDF, starch, sugars, and $\mathrm{N}$ was varied while keeping all other values constant. The variation range chosen was (g/kg DM): NDF 300-600, starch 0-300, sugars 0-300, N 17.5-32.5. Results are reported for four diets: a $0 \mathrm{~g}$ concentrate $/ \mathrm{kg}$ diet at an intake level of 5.3 (diet $\mathrm{RL}$ ) or $17 \cdot 1$ (diet $\mathrm{RH}$ ) $\mathrm{kg} \mathrm{DM} / \mathrm{d}$, and a $667 \mathrm{~g}$ concentrate $/ \mathrm{kg}$ diet at an intake level of $5 \cdot 3$ (diet $\mathrm{CL}$ ) or $17 \cdot 1$ (diet $\mathrm{CH}) \mathrm{kg} \mathrm{DM} / \mathrm{d}$. Some of the dietary inputs (e.g. the all-concentrate diet fed at the highest intake level) are unlikely to be fed without problems. Such dietary inputs merely serve to illustrate the theoretical effect of changes in the diet. In the present paper the total fibrolytic microbial organic matter $(\mathrm{OM})$ in the rumen is the sum of the predicted fibrolytic bacterial and protozoal OM. The simulated contribution of rumen protozoa to fibre degradation was calculated as the amount of NDF taken up and subsequently degraded within the protozoa, divided by the total amount of NDF degraded in the rumen.

\section{RESULTS}

\section{Comparison between predicted and observed values}

In Table 2, observed variables (reported by Robinson et al. 1986, 1987) and variables predicted by the model are presented for five intake levels, as well as the error of predicted values relative to observed values (root mean square prediction error, MSPE; Bibby \& Toutenburg, 1977). It should be noted that Robinson et al. (1987) calculated duodenal 
Table 2. Comparison of experimentally observed variables (Obs) and variables predicted by the model (Pred), and error of predicted values relative to observed values (MSPE), for cows fed on diets at different intake levels* (Observations from Robinson et al. 1986, 1987)

\begin{tabular}{|c|c|c|c|c|c|c|c|c|c|c|c|}
\hline \multirow{2}{*}{$\begin{array}{l}\text { Intake level } \\
(\mathrm{kg} \mathrm{DM} / \mathrm{d}) . .\end{array}$} & \multicolumn{2}{|c|}{$5 \cdot 3$} & \multicolumn{2}{|c|}{$9 \cdot 2$} & \multicolumn{2}{|c|}{$13 \cdot 1$} & \multicolumn{2}{|c|}{$17 \cdot 1$} & \multicolumn{2}{|c|}{$21 \cdot 0$} & \multirow[b]{2}{*}{ MSPF } \\
\hline & Obs & Pred & Obs & Pred & Obs & Pred & Obs & Pred & Obs & Pred & \\
\hline \multicolumn{12}{|l|}{$\begin{array}{l}\text { Duodenal flow } \\
\text { of OM }(g / d)\end{array}$} \\
\hline NDF & 790 & 810 & 1450 & 1630 & 2180 & 2170 & 3420 & 3440 & 4240 & 4230 & 3.5 \\
\hline Total NAN & - & 125 & - & 226 & - & 323 & - & 437 & - & 521 & - \\
\hline Bacterial NAN & - & 63 & - & 107 & - & 158 & - & 201 & - & 252 & - \\
\hline $\begin{array}{l}\text { Protozoal NAN } \\
\text { Concentration } \\
\text { of }(\mathrm{mm})\end{array}$ & - & 6 & - & 11 & - & 13 & - & 16 & - & 16 & - \\
\hline $\mathrm{NH}_{3}$ & 6.9 & $8 \cdot 8$ & $5 \cdot 3$ & $8 \cdot 5$ & $6 \cdot 7$ & $10 \cdot 4$ & $6 \cdot 4$ & $8 \cdot 3$ & 5.0 & $12 \cdot 0$ & $66 \cdot 1$ \\
\hline Total VFA & 93 & 73 & 106 & 94 & 124 & 112 & 119 & 117 & 131 & 127 & $10 \cdot 4$ \\
\hline $\begin{array}{l}\text { Microbial N in } \\
\text { rumen }(\mathrm{g})\end{array}$ & 87 & 91 & 128 & 121 & 157 & 169 & 168 & 173 & 183 & 226 & $10 \cdot 4$ \\
\hline $\begin{array}{c}\text { Microbial OM } \\
\text { (\% of total) }\end{array}$ & & & & & & & & & & & \\
\hline $\begin{array}{c}\text { Fibrolytic } \\
\text { bacterial }\end{array}$ & - & $49 \cdot 3$ & - & $47 \cdot 5$ & - & $53 \cdot 8$ & - & $53 \cdot 4$ & - & $56 \cdot 2$ & - \\
\hline Protozoal & - & $24 \cdot 8$ & - & $26 \cdot 0$ & - & $23 \cdot 7$ & - & 23.6 & - & $21 \cdot 0$ & - \\
\hline $\begin{array}{l}\text { Protozoal NDF } \\
\text { degradation } \\
\text { (\% total } \\
\text { degradation) }\end{array}$ & - & $16 \cdot 7$ & - & $16 \cdot 8$ & - & $14 \cdot 0$ & - & 12.9 & - & $12 \cdot 6$ & - \\
\hline
\end{tabular}

MSPE, mean square prediction error; $\mathrm{NAN}$, non- $\mathrm{NH}_{3}-\mathrm{N} ; \mathrm{NDF}$, neutral-detergent fibre; $\mathrm{OM}$, organic matter; VFA, volatile fatty acids.

NDF flow by dividing faecal NDF flow by $0 \cdot 85$, based on studies of Tamminga (1981). There was a close agreement for duodenal NDF flow between observed and simulated results, with a root MSPE of $3.5 \%$. Both observed and simulated values indicated a decline in rumen NDF degradation as intake increased. As observed in the previous model (Neal et al. 1992), rumen $\mathrm{NH}_{3}$ concentration was seen to be overpredicted with a MSPE of $66 \%$. Both observed and predicted values showed an increase in total volatile fatty acid concentration of rumen fluid as intake increased (MSPE 10.4\%). Rumen microbial N was observed and predicted to increase with each feed intake increment. Robinson et al. (1987) used diaminopimelic acid to estimate microbial $\mathrm{N}$ in the rumen, which is assumed to measure bacterial biomass only, whereas predictions of microbial $\mathrm{N}$ included protozoal $\mathrm{N}$ as well. This might explain the overprediction of microbial $\mathrm{N}$. The lowest simulated proportion of fibrolytic bacterial $O M$ and highest proportion of protozoal $O M$ in the rumen occurred with an intake level of $9.2 \mathrm{~kg} \mathrm{DM} / \mathrm{d}$, and at this level the simulated contribution of protozoa to NDF degradation was $17 \%$ and decreased to $13 \%$ at the highest intake level.

\section{Effect of the intake level and roughage: concentrate ratio}

The predicted amount of protozoal OM in the rumen, the proportion of rumen protozoal $O M$ in the total amount of fibrolytic bacterial and protozoal OM, and the contribution of protozoa to fibre degradation in the rumen, with diets containing $0,333,667$ or $1000 \mathrm{~g}$ 

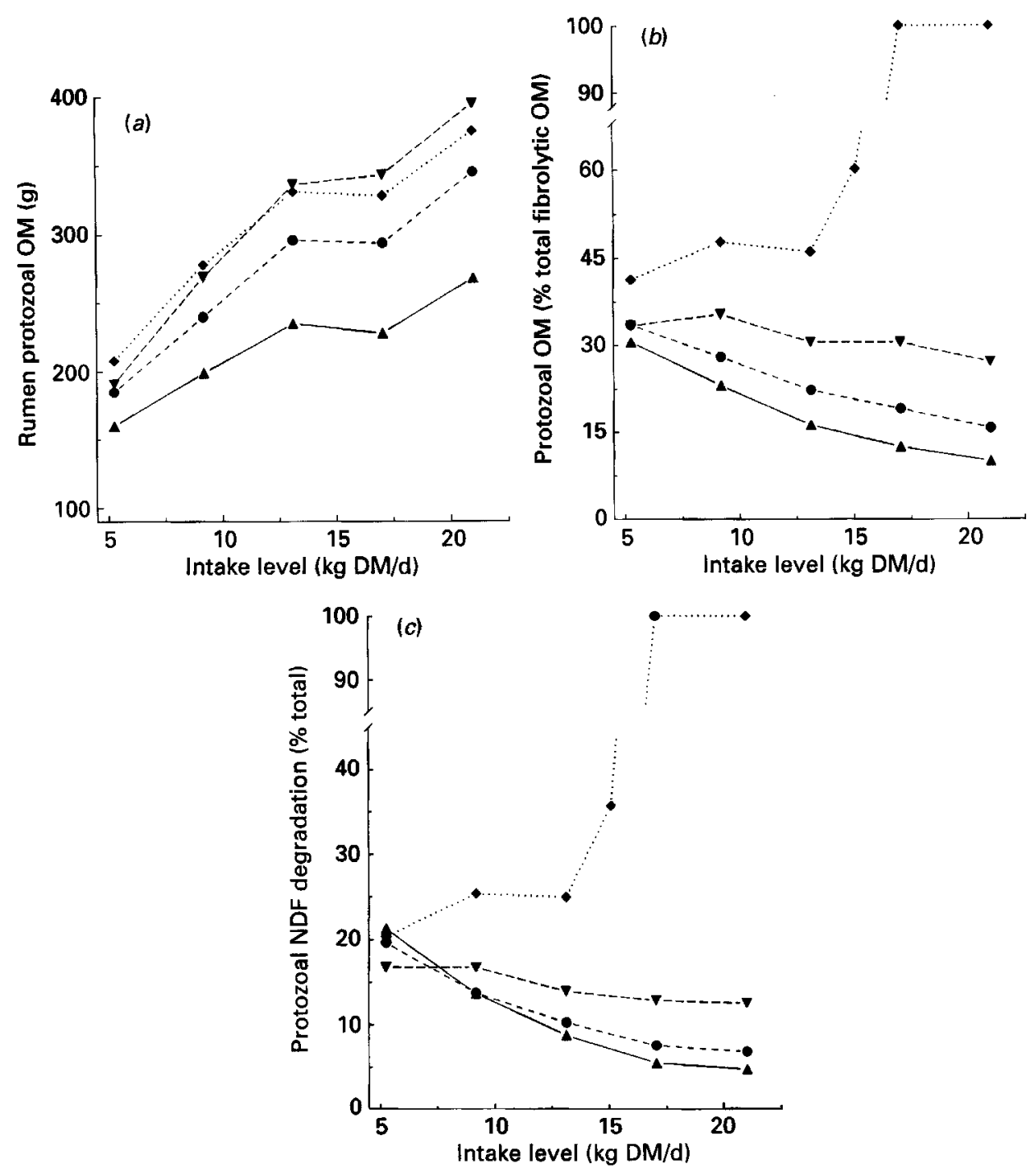

Fig. 1. Predicted effect on (a) protozoal organic matter (OM) in the rumen, $(b)$ protozoal OM in total fibrolytic microbial OM in the rumen and $(c)$ protozoal contribution to neutral-detergent fibre (NDF) degradation in the rumen of DM intake level of diets containing $0(\Delta), 333(\bullet), 667(\nabla)$ or $1000(\diamond) \mathrm{g}$ concentrate $/ \mathrm{kg}$. For details of diets and procedures, see Table 1 and pp. 618-620.

concentrate $/ \mathrm{kg}$ and fed at five intake levels, are shown in Fig. 1( $a, b, c)$. Protozoal OM generally increased in response to increased feeding levels (Fig. $1(a)$ ). The predicted small elevation or even drop in protozoal OM when feed intake was raised from 13.1 to $17 \cdot 1 \mathrm{~kg} \mathrm{DM} / \mathrm{d}$ is the result of the relatively high solid passage rate at the $17 \cdot 1 \mathrm{~kg} \mathrm{DM} / \mathrm{d}$ level, adopted from Robinson et al. (1987). Protozoal OM was always lowest with the allroughage diet and generally increased when concentrate replaced roughage. However, with higher intake levels the increased availability of easily fermentable carbohydrates on the allconcentrate diets caused the fractional death rate of protozoa to increase rapidly (Dijkstra, 1994). As a result, the predicted protozoal OM with the all-concentrate diet was lower than 
that with the $667 \mathrm{~g}$ concentrate $/ \mathrm{kg}$ diet for intake levels exceeding $12 \mathrm{~kg} \mathrm{DM} / \mathrm{d}$. The proportion of protozoal $\mathrm{OM}$ in the total fibrolytic microbial $\mathrm{OM}$ in the rumen was generally predicted to decline with an increase in feed intake, but with the all-concentrate diet this proportion was increased (Fig. 1(b)). Intake of the all-concentrate diet exceeding $15 \mathrm{~kg} \mathrm{DM} / \mathrm{d}$ resulted in the predicted elimination of fibrolytic bacteria due to the relatively low amount of substrate available, the low $\mathrm{pH}$ of rumen fluid and the high fractional outflow rate of solids. Hence, the proportion of predicted protozoal OM relative to fibrolytic microbial OM was 1 . Thus, high intake of the all-concentrate diet resulted in a low rumen NDF degradation (only $8 \%$ of intake), entirely related to the metabolic activity of rumen protozoa (Fig. 1(c)). With lower inclusions of concentrate in the diet the highest protozoal contribution to NDF degradation at the low intake level was predicted to occur with the all-roughage diet $(21,20$ and $17 \%$ with 0,333 and $667 \mathrm{~g}$ concentrate $/ \mathrm{kg}$ diet respectively). By contrast, when feed intake level was increased up to $21 \mathrm{~kg} \mathrm{DM} / \mathrm{d}$ this contribution with the all-roughage diet declined to $5 \%$, while on the $667 \mathrm{~g}$ concentrate $/ \mathrm{kg}$ diet the decline was much less pronounced ( $13 \%$ with highest feed intake level).

\section{The effect of chemical composition of the feed}

The predicted responses of protozoal OM in the rumen, of the proportion of protozoal OM in the total fibrolytic microbial OM and of the contribution of protozoa to NDF degradation to variations in NDF content of the diet are shown in Fig. 2(a,b,c), for allroughage (R) or $667 \mathrm{~g}$ concentrate $/ \mathrm{kg}(\mathrm{C})$ diets fed at low $(\mathrm{L} ; 5.3 \mathrm{~kg} \mathrm{DM} / \mathrm{d})$ or high $(\mathrm{H}$; $17 \cdot 1 \mathrm{~kg} \mathrm{DM} / \mathrm{d}$ ) intake levels. Protozoal OM in the rumen was predicted to be unaffected by increases in the dietary NDF content (Fig. 2(a)), whereas there was an increase in fibrolytic bacterial OM because substrate availability was increased. Consequently, the proportion of protozoal OM in fibrolytic microbial OM decreased (Fig. 2(b)), as well as the contribution of protozoa to fibre degradation (Fig. 2(c)). These changes were most pronounced on diet RL, and particularly so with low NDF levels.

In contrast with the predicted response of protozoal OM to variations in dietary NDF level, increases in dietary starch level resulted in elevated rumen protozoal OM. The relationship between starch content and protozoal $\mathrm{OM}$ in the rumen was almost linear, except for diet $\mathrm{CH}$ (Fig. $3(\mathrm{a})$ ). With this particular diet the fractional death rate of protozoa increased rapidly, due to a high availability of easily degradable substrates. Except for the initial decrease with diet $\mathrm{CL}$ the proportion of protozoal $\mathrm{OM}$ in fibrolytic microbial $\mathrm{OM}$ decreased (Fig. 3(b)). The predicted contribution of protozoa to NDF degradation (Fig. $3(c)$ ) tended towards a minimum value at about $100 \mathrm{~g}$ starch $/ \mathrm{kg}$ DM. The model predicted that small additions of starch to a diet lacking starch increased the amount of storage polysaccharides within protozoa and, thus, reduced the amount of particulate material engulfed, including fibre and fibrolytic bacteria (Dijkstra, 1994). This resulted in a reduction in protozoal contribution to fibre degradation. Further additions of starch did increase the protozoal contribution to NDF degradation, because the decline in protozoal contribution to NDF degradation due to increased protozoal storage material was more than compensated for by an increase in protozoal OM.

The effects of variations in dietary sugar content on protozoal OM depended on the roughage: concentrate ratio as well as feeding level (Fig. 4(a)). When the all-roughage diet, devoid of starch, was fed and the soluble sugar content set at $0 \mathrm{~g} / \mathrm{kg} \mathrm{DM}$, protozoa were predicted to disappear completely and NDF degradation was related entirely to bacterial activity (Fig. 4(c)). The only substrate available (NDF) did not support sufficient protozoal growth to prevent disappearance through death and passage to the omasum. Incidentally, due to the absence of preferred substrate, amylolytic bacteria were eliminated as well. Small additions of sugars rapidly increased predicted protozoal OM, and the contribution of 

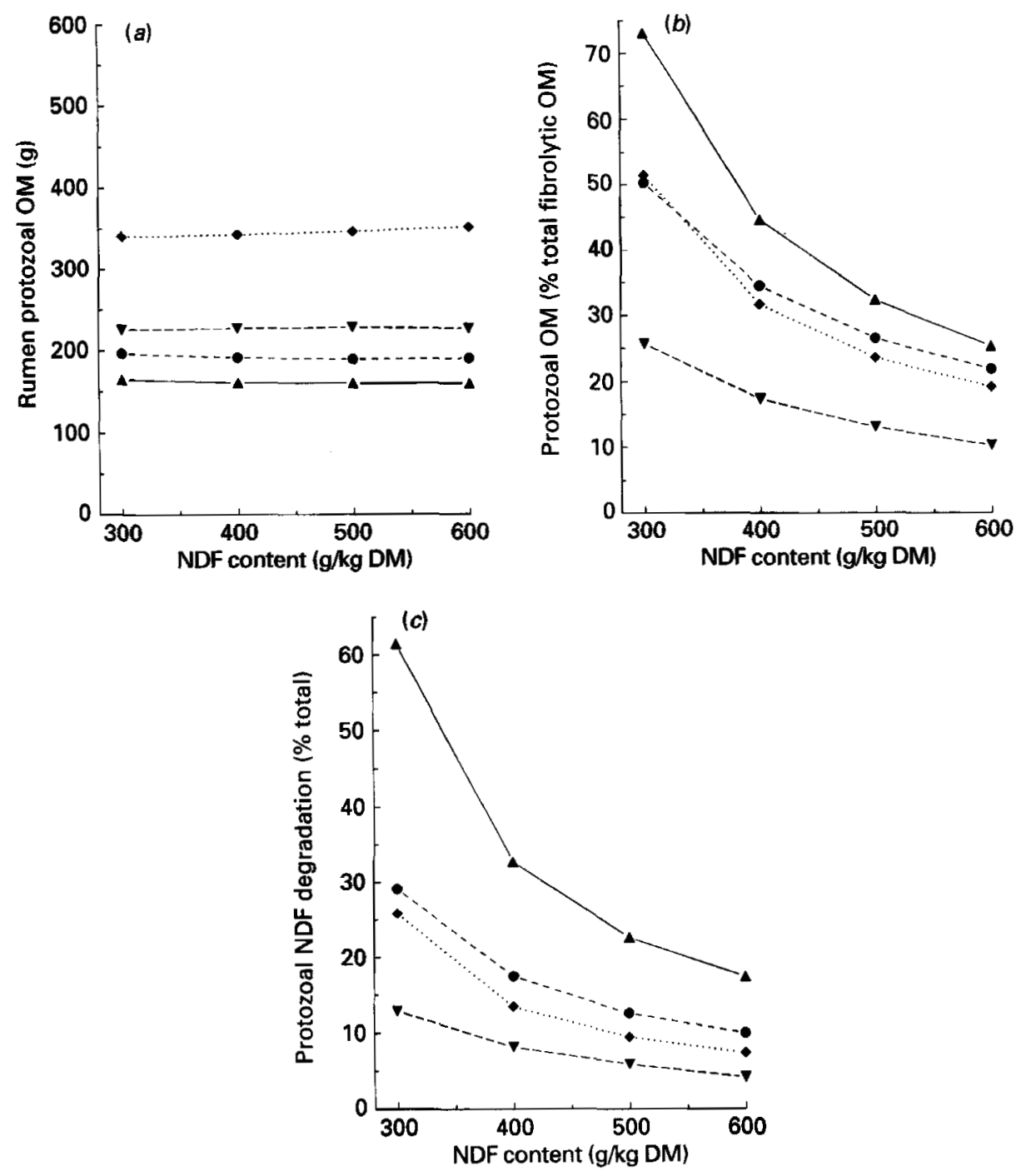

Fig. 2. Predicted effect on (a) protozoal organic matter (OM) in the rumen, (b) protozoal OM in total fibrolytic microbial OM in the rumen and $(c)$ protozoal contribution to neutral-detergent fibre (NDF) degradation in the rumen of dietary NDF level of all-roughage diets fed at 5.3 (diet RL; $\Delta$ ) or 17.1 (diet RH; $\mathbf{\nabla}$ ) kg DM/d and of $667 \mathrm{~g}$ concentrate $/ \mathrm{kg}$ diets fed at $5 \cdot 3$ (diet $\mathrm{CL} ; 0$ ) or $17.1($ diet $\mathrm{CH} ; \bullet) \mathrm{kg} \mathrm{DM} / \mathrm{d}$. For details of diets and procedures, see Table 1 and pp. 618-620.

protozoa to NDF degradation when sugar content was set at $100 \mathrm{~g} / \mathrm{kg} \mathrm{DM}$ was raised to 20 and $6 \%$ with diets RL and RH respectively. Further sugar additions, however, caused the fractional death rate of protozoa to increase, and protozoal contribution to NDF degradation increased (diet RL) or decreased (diet RH) slightly. The decline in protozoal OM was most pronounced with diet $\mathrm{CH}$ (Fig. 4(a)). However, at high sugar availability the partitioning of utilization of sugars for protozoal growth or protozoal storage material formation was shifted in favour of the former (Dijkstra, 1994). This resulted in a decreased amount of storage material within the protozoa and a small increase in protozoal NDF degradation with diet $\mathrm{CH}$ (12 and $15 \%$ with 0 and $300 \mathrm{~g}$ sugar/kg DM respectively). 

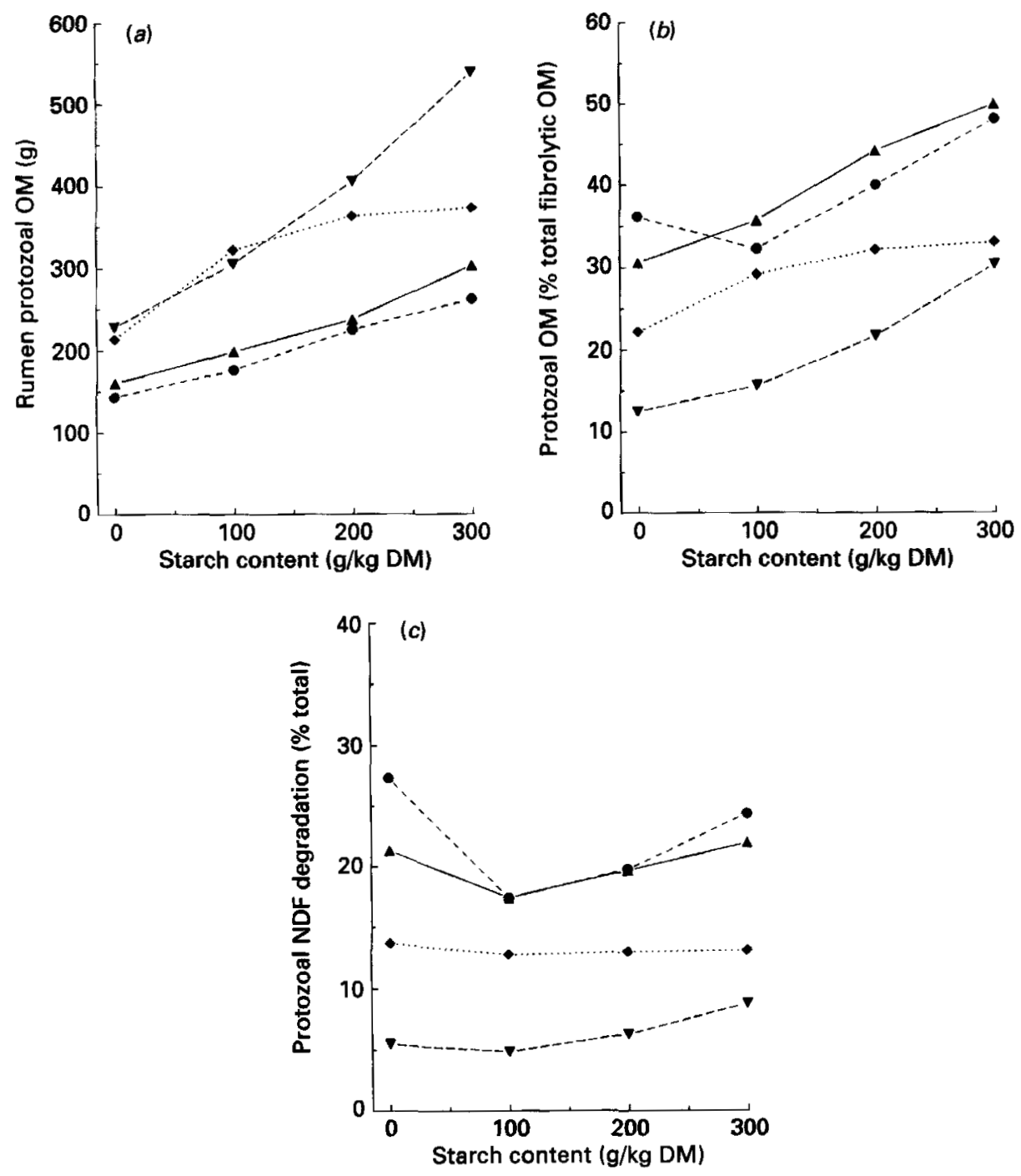

Fig. 3. Predicted effect on (a) protozoal organic matter (OM) in the rumen, $(b)$ protozoal OM in total fibrolytic microbial OM in the rumen and (c) protozoal contribution to neutral-detergent fibre (NDF) degradation in the rumen of dietary starch level of all-roughage diets fed at $5 \cdot 3$ (diet $\mathrm{RL} ; \mathbf{\Delta}$ ) or $17 \cdot 1$ (diet $\mathrm{RH} ; \boldsymbol{\nabla}$ ) $\mathrm{kg} \mathrm{DM} / \mathrm{d}$ and of $667 \mathrm{~g}$ concentrate $/ \mathrm{kg}$ diets fed at 5.3 (diet $\mathrm{CL} ; O$ ) or $17 \cdot 1$ (diet $\mathrm{CH} ; \bullet$ ) $\mathrm{kg} \mathrm{DM} / \mathrm{d}$. For details of diets and procedures, see Table 1 and pp. 618-620.

Variations in the $\mathrm{N}$ content of the diet between 17.5 and $32.5 \mathrm{~g} / \mathrm{kg}$ DM (i.e. crude protein $(\mathrm{N} \times 6.25)$ levels between 11 and $20 \%$ ) generally reduced the predicted amount of protozoal OM slightly (Fig. 5(a)), whereas fibrolytic bacterial OM increased. Hence, a decreased proportion of protozoal $\mathrm{OM}$ in fibrolytic microbial $\mathrm{OM}$ was predicted in response to increases in dietary $\mathbf{N}$ level (Fig. $5(b)$ ). These changes in amounts of protozoal and bacterial OM are related to the assumptions made in the model, that an increased rumen $N$ availability will increase bacterial growth efficiency, whereas protozoal growth efficiency is not affected because protozoa already engulf large amounts of microbial and feed protein 

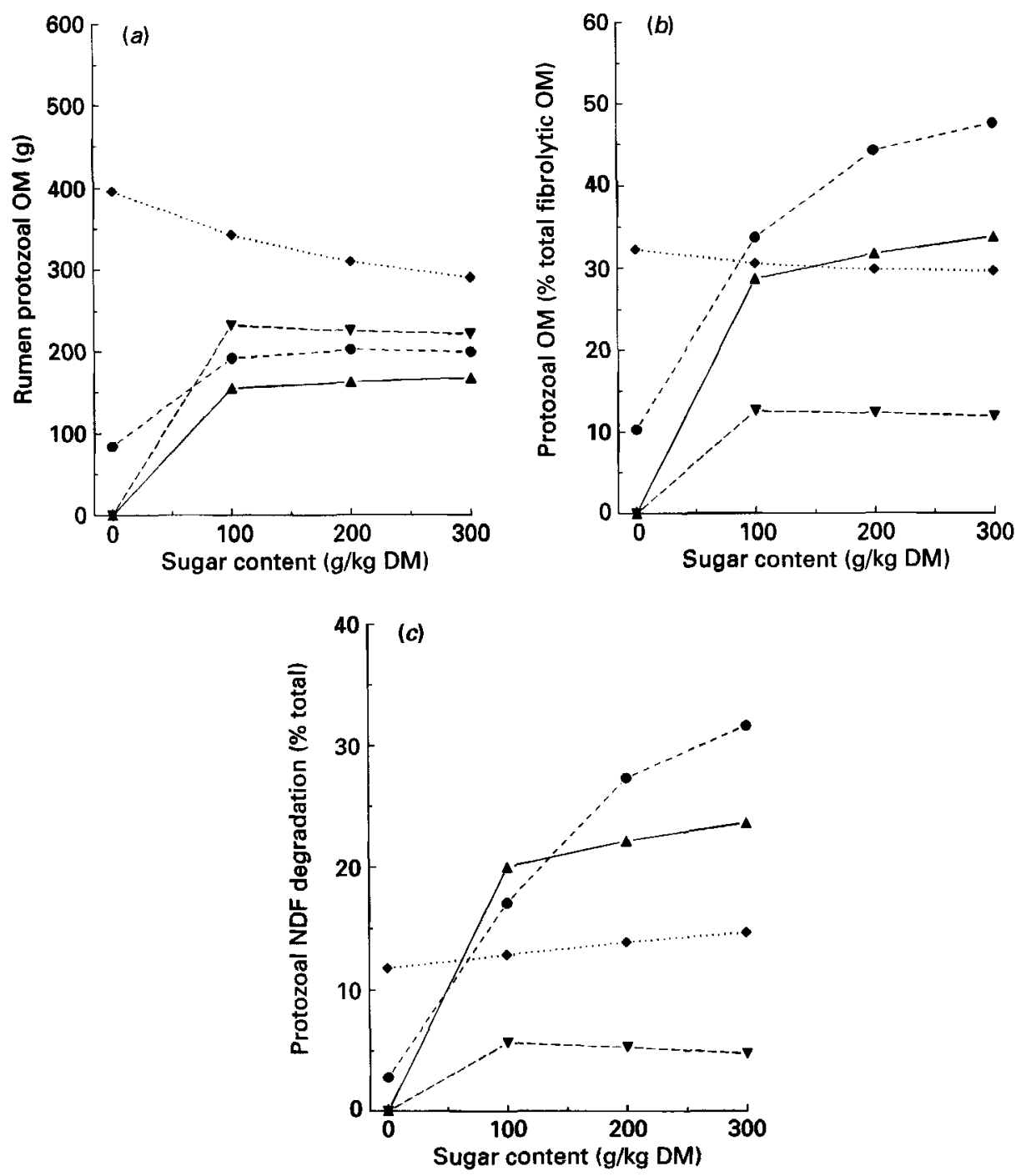

Fig. 4. Predicted effect on (a) protozoal organic matter $(\mathrm{OM})$ in the rumen, (b) protozoal $\mathrm{OM}$ in total fibrolytic microbial OM in the rumen and $(c)$ protozoal contribution to neutral-detergent fibre (NDF) degradation in the rumen of dietary sugar level of all-roughage diets fed at 5.3 (diet RL; $\Delta$ ) or 17.1 (diet RH; $\mathbf{\nabla}) \mathrm{kg} \mathrm{DM} / \mathrm{d}$ and of $667 \mathrm{~g}$ concentrate $/ \mathrm{kg}$ diets fed at $5 \cdot 3($ diet $\mathrm{CL} ; 0$ ) or 17.1 (diet $\mathrm{CH} ; \bullet) \mathrm{kg} \mathrm{DM} / \mathrm{d}$. For details of diets and procedures, see Table 1 and pp. 618-620.

(Dijkstra, 1994). Consequently, except for diet RH, increments in dietary $\mathrm{N}$ level decreased the contribution of protozoa to NDF degradation (from 22, 23 and $15 \%$ with $17.5 \mathrm{~g} \mathrm{~N} / \mathrm{kg} \mathrm{DM}$ and diets $\mathrm{RL}, \mathrm{CL}$ and $\mathrm{CH}$ respectively to 20,11 and $12 \%$ with $32.5 \mathrm{~g} \mathrm{~N} / \mathrm{kg} \mathrm{DM}$ and diets $\mathrm{RL}, \mathrm{CL}$ and $\mathrm{CH}$ respectively; Fig. 5(c)). The small rise in protozoal contribution with diet $\mathrm{RH}$ (5 and $6 \%$ with the lowest and highest $\mathrm{N}$ level respectively) can be explained by the involvement of amylolytic bacteria. At the lowest $\mathrm{N}$ level the predicted low availability of $\mathrm{NH}_{3}$ and amino acids in rumen fluid reduced amylolytic bacterial growth to a large extent. This resulted in a high substrate availability (particularly sugars) for protozoal growth and in turn in a very high protozoal death rate, 

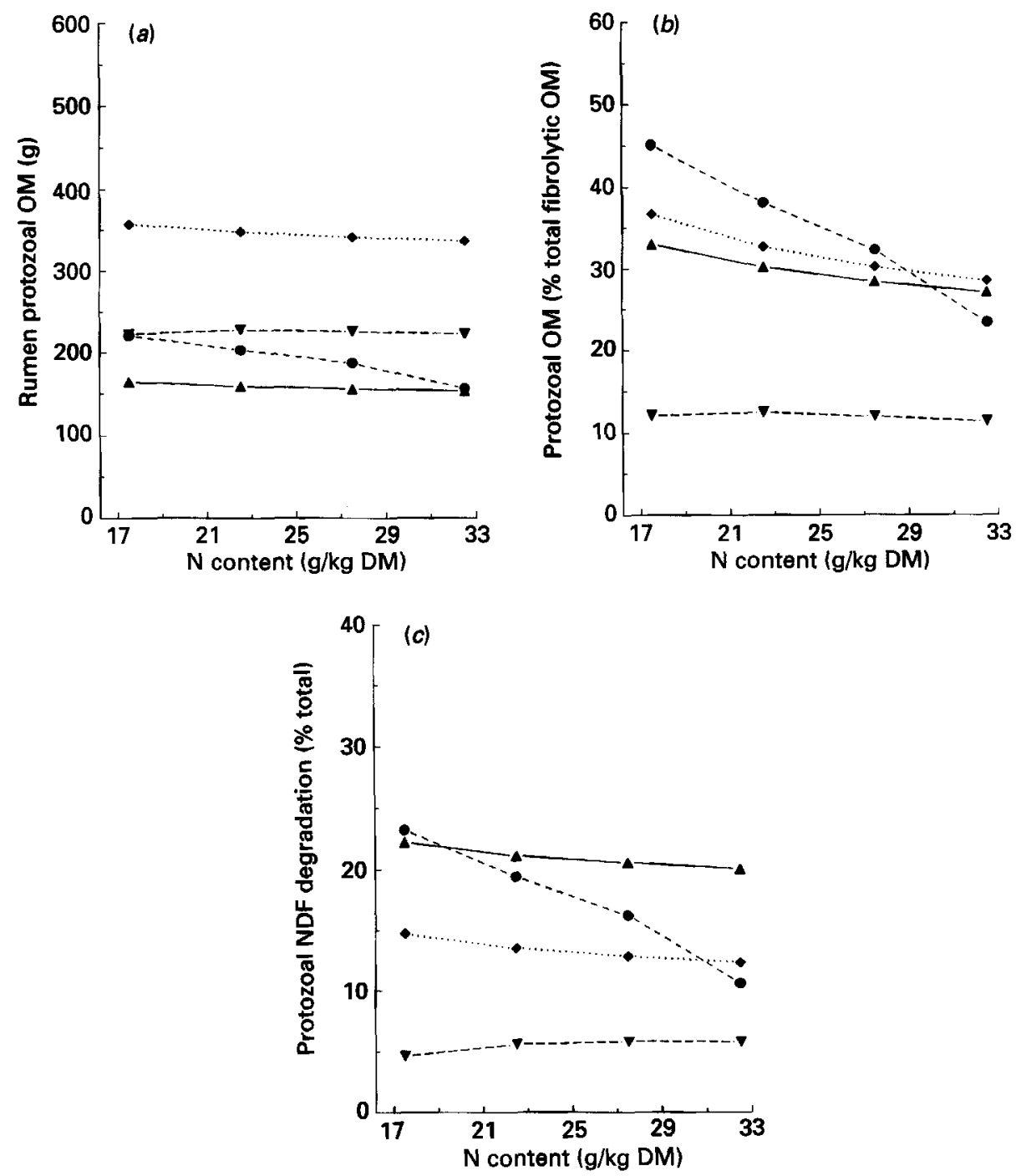

Fig. 5. Predicted effect on (a) protozoal organic matter (OM) in the rumen, $(b)$ protozoal OM in total fibrolytic microbial OM in the rumen and $(c)$ protozoal contribution to neutral-detergent fibre (NDF) degradation in the rumen of dietary nitrogen level of all-roughage diets fed at $5 \cdot 3$ (diet RL; $\Delta$ ) or $17 \cdot 1$ (diet RH; $\mathbf{V}$ ) $\mathrm{kg} \mathrm{DM} / \mathrm{d}$ and of $667 \mathrm{~g}$ concentrate $/ \mathrm{kg}$ diets fed at 5.3 (diet $\mathrm{CL} ; \mathrm{O}$ ) or 17.1 (diet $\mathrm{CH} ; \bullet$ ) $\mathrm{kg} \mathrm{DM} / \mathrm{d}$. For details of diets and procedures, see Table 1 and pp. 618-620.

reducing protozoal $\mathrm{OM}$ as well. Increasing the $\mathrm{N}$ level increased bacterial growth and reduced substrate supply to protozoa and consequently protozoal growth. However, this reduction was more than compensated for by the reduction in protozoal fractional death rate, which finally resulted in increased protozoal OM. This increased the amount of fibrolytic bacteria engulfed. Hence, although fibrolytic bacterial growth with diet RH was more efficient with higher dietary $\mathrm{N}$ levels, the amount of fibrolytic bacterial OM declined. 


\section{DISCUSSION}

To our knowledge, there are no published in vivo data on the amounts of NDF degraded in the rumen by protozoa, relative to the amounts degraded by bacteria, when both protozoa and bacteria are present in the rumen. Estimates of in vitro DM disappearance of forages related to protozoal activity have been reported (Amos \& Akin, 1978), as well as protozoal enzymic activity against cell wall components (Coleman, 1986 b). In some studies the effect of defaunation on fibre degradation in the rumen has been reported (for reviews, see Demeyer, 1989; Jouany, 1989; Ushida et al. 1991). These results will be discussed later in relation to the results of the simulations reported in the present paper. In the present study the role of protozoa and bacteria in fibre degradation was examined using a mathematical model of microbial metabolism in the rumen. The model provides a framework in which knowledge on protozoal-bacterial interrelationships is integrated and hypotheses formulated to represent key aspects of protozoal and bacterial metabolism. Although quantitatively limited, biological principles, including uptake of bacteria by protozoa, selective retention of protozoa in the rumen, and microbial substrate preferences, have been examined and a number of comprehensive reviews on protozoal metabolism have been published (e.g. Coleman, 1986a; Jouany et al. 1988; Williams \& Coleman, 1988; Ushida et al. 1991). The way in which observations on principal aspects of protozoal metabolism were turned into mathematical representations has been described previously (see pp. 618-619). In the following sections the assumptions in the model with respect to NDF degradation and simulated patterns of protozoal and bacterial OM in response to dietary changes will be discussed.

Comparisons between model predictions and experimental observations, using the ${ }^{14} \mathrm{C}$ dilution technique in cattle and sheep, indicated reasonable agreement for protozoal biomass in the rumen (Dijkstra, 1994). Increasing the concentrate content of the diet increased the protozoal OM in the rumen at all intake levels, except for the all-concentrate diet fed at higher intake levels (Fig. 1(a)), and resulted in a higher proportion of protozoa in total fibrolytic microbial OM in the rumen (Fig. 1(b)). Predicted responses of protozoa and fibrolytic bacteria to changes in the chemical composition of the diet (Figs. 2-5) indicated that the effects of roughage:concentrate ratio were related mainly to the NDF and starch contents of the diet. These predictions were qualitatively in line with observations. Large protozoal populations are generally found with diets consisting of equal amounts of roughages and concentrates, whereas high feeding levels of high-grain diets reduced protozoal numbers or even eliminated protozoa (for review, see Jouany, 1989). However, Towne et al. (1990) reported that protozoa constituted a significant proportion of the total rumen microbial population of beef cattle fed ad lib. on high-grain diets, resulting in low $\mathrm{pH}$ values of rumen fluid. The predicted disappearance of fibrolytic bacteria with all-concentrate diets at higher intake levels (Fig. 1(b)), on which the pH of rumen fluid is expected to be low, is supported by the complete washout of fibrolytic bacterial species observed in vitro at low $\mathrm{pH}$ values (Russell \& Dombrowski, 1980). It should be noted though that the concentrate on which the simulations were based contained a relatively large amount of fibrous by-products, and was characterized by a high NDF content $(355 \mathrm{~g} / \mathrm{kg})$ and a rather low starch and sugars content $(265 \mathrm{~g} / \mathrm{kg}$; Robinson et al. 1986). The predicted effects of the roughage:concentrate ratio would be more pronounced had the starch level of the concentrate been higher, as can be seen from the predicted increase in protozoal OM when dietary starch (Fig. 3(a)) was increased. The ability of rumen protozoa to utilize both dietary and microbial proteins influenced the value for protozoal bacterial biomass in the rumen, in response to changes in dietary $\mathrm{N}$ levels (Fig. 5(a,b)). Predicted protozoal OM was often slightly reduced and fibrolytic bacterial 
OM raised when dietary $\mathrm{N}$ level was increased. Indeed, in vivo, protozoal $\mathrm{N}$ in the rumen was lower on a diet supplemented with casein ( $1.4 \mathrm{~g}$ protozoal $\mathrm{N}$; Leng, 1982) compared with that on the unsupplemented $\operatorname{diet}(2.4 \mathrm{~g}$ protozoal $\mathrm{N}$; Leng et al. 1984). Decreasing the $\mathrm{N}$ availability of soyabean meal by treatment with formaldehyde slightly increased (although not significantly) protozoal $\mathrm{N}$ pool size and decreased fluid-phase bacterial $\mathrm{N}$ pool size (Krebs et al. 1989). Overall, these simulations, in which dietary components and composition were varied, showed qualitative agreement with observations.

Evaluation of a previous model, on which the present model was largely based, against a wide range of dietary inputs showed that the degradation of NDF in the rumen was predicted satisfactorily (Neal et al. 1992). Equally, the results presented in Table 2 showed that predicted NDF degradation matched corresponding values estimated from NDF faecal flow, reported by Robinson et al. (1987). In the model it was assumed that both protozoa and bacteria are involved in the degradation of NDF. This is a simplification of the rumen ecosystem, because fungi might have a significant role in degradation of fibre in the rumen (for review, see Trinci et al. 1994). However, quantitative data on growth and metabolism of rumen fungi are very scarce and, hence, the metabolic activity of this group was not included in the model. Furthermore, evaluation of the model used experimental results with a high-quality diet and under such dietary conditions fungi do not play an important role in the rumen ecosystem (Grenet et al. 1989). The NDF-degrading activities of rumen bacteria and protozoa were assumed to be directly proportional to (amongst others) the amounts of polysaccharide-free microbial matter present. Although such a representation is common to models of rumen fermentation, it should be noted that metabolic activity of micro-organisms varies within and between species, and amounts of micro-organisms alone are not necessarily the most vital measure to evaluate the metabolic significance of a group of organisms within an ecosystem (Brock, 1966). Differences in cellwall-degrading activities between cellulolytic bacterial species (e.g. the lower cellulolytic activity of Ruminococcus flavefaciens compared with $R$. albus; Van Gylswyck \& Labuschagne, 1971) and protozoal species (e.g. general absence or low activity of cellulases and hemicellulases in Entodinium species and holotrich protozoa and higher activities in larger Entodiniomorphids; Coleman, 1986b) were represented to a minor extent only, in view of the absence of adequate data and problems encountered previously in representing several species within an ecosystem (Dijkstra et al. 1990). It was assumed that uptake and subsequent degradation of NDF by protozoa was inhibited in the presence of storage polysaccharide material within the protozoa (Coleman, 1992). In simulations where dietary starch content was varied (Fig. 3), protozoal NDF degradation at zero starch levels was $14.0,14.6,9.4$ and $13.9 \mathrm{mmol} / \mathrm{g}$ protozoal OM per d with diets $\mathrm{RL}, \mathrm{CL}, \mathrm{RH}$ and $\mathrm{CH}$ respectively, whereas increases in dietary starch content to $300 \mathrm{~g} / \mathrm{kg} \mathrm{DM}$ decreased these values to $6 \cdot 6,7 \cdot 3,6.0$ and $7.6 \mathrm{mmol} / \mathrm{g}$ protozoal OM per $\mathrm{d}$. This decline in NDF-degrading activity might reflect the relatively large increase in numbers of Entodinium spp., generally observed when diets rich in starch are fed compared with all-roughage diets (Jouany, 1989), and the low cellulolytic and hemicellulolytic activity of these species (Coleman, 1986 b). Small additions of soluble sugars decreased protozoal NDF-degrading activity as well. However, particularly with high-concentrate diets, further increases in dietary soluble sugar content slightly increased protozoal NDF-degrading activity. Such an initial decrease in NDF-degrading activity might be related to the rapid proportional increase in holotrich protozoa generally observed when soluble sugars are added to a diet, and the relative inactivity of holotrichs against cellulose and hemicellulose (Jouany, 1989). Diets rich in sugars caused lysis of holotrich protozoa, related to the inability to regulate the uptake rate of soluble sugars (for review, see Williams, 1986) and, consequently, the remaining protozoal population might have a higher NDF-degrading activity. Thus, the model 
simulates, at least qualitatively, differences in NDF-degrading activities of the entire rumen protozoal population in response to changes in dietary composition, in line with characteristics of individual protozoal species and their presence in the rumen with different diets.

The simulated variations in NDF-degrading activities of rumen protozoa and variations in protozoa: fibrolytic bacteria caused marked differences in the contribution of protozoa to NDF degradation. Except with the all-concentrate diet, higher feed intake levels resulted in lower contributions of rumen protozoa to NDF degradation (Fig. 1(c)). With the allconcentrate diet fibrolytic bacteria were predicted to disappear and at the highest intake level rumen NDF degradation was only $8 \%$. Low NDF degradation values with allconcentrate diets or high intake levels have been reported in the literature (for example, McCarthy et al. 1989). The model predicted an increased contribution of protozoa to NDF degradation in response to replacement of roughages by concentrates, except with low intake levels. However, simulations in which the dietary chemical composition was varied indicated that protozoal contribution at the low feed intake level might have been raised with an increase in concentrate level, had the concentrate contained less NDF and more starch (confirmed by simulations of which results are not shown). The contribution of protozoa to fibre degradation generally decreased in response to added $\mathbf{N}$ as well (Fig. $5(c))$.

It should be noted that model predictions of NDF degradation merely represented NDF engulfed by and degraded within protozoal cells, without indication of the origin (bacterial or protozoal) of enzymes involved. Williams \& Coleman (1988) stated in their review that some authors have found indirect evidence that at least a proportion of these enzymes is of protozoal origin, but also stated that other authors have questioned these findings. In vitro the degradation of cellulose was improved when protozoa were added to a suspension of bacteria (Yoder et al. 1966), while Hidayat et al. (1993) reported that the addition of protozoa to a bacterial suspension which was at the optimum concentration for fermentation did not further increase fermentation. Additions of autoclaved or frozen and thawed protozoa increased cellulose degradation as well, although to a smaller extent (Yoder et al. 1966), suggesting that factors or mechanisms other than the relevant protozoal enzymes were also involved. Thus, both the direct protozoal hemicellulolytic and cellulolytic enzyme activities, as well as other protozoal characteristics, including engulfment of bacteria, competition for substrates and stabilizing effects on rumen fluid characteristics are of importance in the relative contributions of protozoa and bacteria to degradation of cell wall material. The integrative nature of these processes and the inability to determine protozoal contribution directly in the faunated rumen have led to different opinions on the importance of protozoa in fibre degradation. Hungate (1975) stated that the amount of cellulose digested by rumen protozoa is small compared with that digested by bacteria, whereas Coleman (1988) reported the opposite. The results of the simulations indicate a contribution of 5-35\% in cattle fed on a variety of diets at intake levels below $15 \mathrm{~kg} \mathrm{DM} / \mathrm{d}$. With more extreme diets protozoal contributions of $0 \%$ (when diets are devoid of starch and soluble sugars) or $100 \%$ (high-concentrate diets at high intake levels) have been simulated. Comparatively, fractionating studies in continuous artificial systems revealed that ciliates accounted for $19-28 \%$ of total cellulase activity on a mixture of filter paper cellulose and ground lucerne (Medicago sativa; Gijzen et al. 1988). Yoder et al. (1966) reported a cellulose digestion coefficient of $7 \%$ with washed suspensions of protozoa in vitro and Amos \& Akin (1978) reported that rumen protozoa degraded 4-11\% of intact orchardgrass (Dactylis glomerata) and bermudagrass (Cynodon dactylon) tissue.

Demeyer (1981) calculated from data on the effects of defaunation on plant-cell-wall degradation in vitro or in sacco that protozoa were responsible for $30-40 \%$ of total fibre 
degradation, a value which has been quoted frequently by other authors (e.g. Jouany et al. 1988; Williams \& Coleman, 1988). However, this is not necessarily the direct quantitative contribution of protozoa to fibre degradation. Other effects of defaunation might contribute to the explanation of the effects of defaunation on fibre degradation. These include the reduced $\mathrm{NH}_{3}$ levels and reduced $\mathrm{pH}$ of rumen fluid (for review, see Jouany et al. 1988), increased (Orpin \& Letcher, 1984) or decreased (Kayouli et al. 1984; Ushida et al. 1986) rumen fluid volume and fluid- and solid-phase retention times, and toxic effects on bacteria of chemical agents applied to remove protozoa (Jouany et al. 1988). Furthermore, in defaunated animals the population of fungi is often increased and an enhanced role of fungi in NDF degradation is likely (Jouany, 1989). Protozoa are less active in the turnover of fungal protein than bacterial protein, and increases in the fungal population on defaunation are usually smaller than increases seen in the bacterial population (Newbold \& Hillman, 1990). Apart from these effects the simulations give some indication of the effects of defaunation on NDF degradation in the rumen. Defaunation invariably reduced in vivo NDF or acid-detergent fibre (ADF) degradation in the rumen (Veira et al. 1983; Kayouli et al. 1986; Punia et al. 1987; Ushida \& Jouany, 1990; Ushida et al. 1990; Hsu et al. 1991), but the magnitude of the reduction differed widely. Studies on the effect of defaunation on in sacco NDF or ADF disappearance yielded more variable results, however, and both increases and decreases have been reported (for reviews, see Demeyer, 1989; Jouany, 1989). Except for the experiment of Punia et al. (1987), the in vivo experiments were performed with sheep at low intake levels (between 37 and $59 \mathrm{~g} \mathrm{DM} / \mathrm{kg}$ metabolic live weight). The simulations on dairy cattle at the lowest intake level ( $5.3 \mathrm{~kg} \mathrm{DM} / \mathrm{d}$ or $43 \mathrm{~g} \mathrm{DM} / \mathrm{kg}$ metabolic live weight) indicated a relatively high protozoal contribution to NDF degradation (17-21\%). Thus, unless fibrolytic bacterial number or fibrolytic bacterial activity is increased to compensate protozoal fibre degradation, at such low intake levels defaunation might decrease fibre degradation in the rumen. At higher intake levels the simulated protozoal contribution was lower and, consequently, defaunation might result in a less-changed fibre degradation. Defaunation often resulted in an increase in the total number of bacteria (for review, see Jouany et al. 1988), because protozoa prey on bacteria and both groups compete for available substrates. Removal of protozoa allows more bacteria to colonize plant fibres, filling the niche previously occupied by protozoa (Newbold et al. 1989). However, defaunation was shown to cause a shift in bacterial species present in the rumen. Kurihara et al. (1978) and Williams \& Withers (1991) observed an increase in amylolytic bacterial numbers and a decrease in fibrolytic bacterial numbers, and defaunation resulted in a partial substitution of Ruminococcus albus by $R$. flavefaciens. Upon defaunation the activities of the polysaccharide-degrading enzymes were decreased in microbial populations associated with the digesta solids (Newbold et al. 1989; Williams \& Withers, 1991). Thus, an increase in fibrolytic bacterial activity due to removal of protozoa to compensate protozoal fibre degradation might not occur. In cattle fed on high-grain diets, protozoa can moderate the rumen fermentation rate and consequently rumen pH (Nagaraja et al. 1992). Particularly with diets low in fibre and rich in starch and sugars, defaunation will probably reduce fibrolytic bacterial activity because of the lower $\mathrm{pH}$ of rumen fluid at these diets, and the detrimental effect of low $\mathrm{pH}$ values on fibrolytic bacterial growth (Russell \& Dombrowski, 1980). Consequently, the higher protozoal contribution to fibre degradation predicted when dietary starch and sugar levels were increased at the expense of dietary NDF levels (Figs. 2-4) will probably not be compensated for by an increased fibrolytic bacterial activity. With such diets defaunation would be expected to decrease fibre degradation in the rumen to a larger extent than with roughage diets. Indeed, Ushida \& Jouany (1990) observed a larger decrease due to defaunation in NDF degradation with a $650 \mathrm{~g}$ lucerne hay and $300 \mathrm{~g}$ barley/ $\mathrm{kg}$ diet (NDF 
degradation reduced from 41 to $28 \%$ ) than with a $670 \mathrm{~g}$ straw and $280 \mathrm{~g}$ concentrate (beet pulp, soyabean cake and groundnut meal) $/ \mathrm{kg}$ diet (from 51 to $45 \%$ ). Equally, Ushida et al. (1990) reported a much larger decrease in NDF degradation with a $750 \mathrm{~g}$ straw and $190 \mathrm{~g}$ maize $/ \mathrm{kg}$ diet than a $940 \mathrm{~g}$ straw $/ \mathrm{kg}$ diet (reductions from 59 to $41 \%$ and from 64 to $59 \%$ respectively). Hsu et al. (1991) fed sheep $630 \mathrm{~g}$ roughage and $370 \mathrm{~g}$ concentrate $/ \mathrm{kg}$ diets and observed a significant increase in NDF degradation with defaunated animals fed on this diet supplemented with $\mathrm{NaHCO}_{3}$, resulting in a higher $\mathrm{pH}$ of rumen fluid compared with faunated animals fed on the unsupplemented diet (42 and $34 \%$ respectively). Romulo et al. (1989) reported increases in the in sacco NDF digestibility on wheat-straw diets resulting from defaunation, and showed interactions between defaunation and protein supplementation on fibre degradation. Indeed, simulations showed a decreased protozoal contribution to NDF degradation when dietary $\mathrm{N}$ levels were raised, except with diet $\mathrm{RH}$ (Fig. 5(c)). Thus, in defaunated animals fed on low-N diets fibrolytic bacterial activity should be increased to a greater extent to compensate for the loss in protozoal fibre degradation when compared with high- $\mathrm{N}$ diets. A lack of fermentable $\mathrm{N}$ for the rumen bacteria may result in a lowered extent of fermentation and uncoupling of fermentation (Hume et al. 1970; Mehrez et al. 1977). The $\mathrm{NH}_{3}$ concentration in rumen fluid is almost invariably lower in defaunated animals (for review, see Jouany et al. 1988). Hence, compensation for the loss in protozoal fibre degradation in defaunated animals fed on low$\mathrm{N}$ diets might not occur.

In conclusion, the model provided a mathematical representation of the metabolic activities of amylolytic and fibrolytic bacteria and of protozoa in the rumen. It provided an integration of the effects of dietary composition and feed intake level on the different microbial groups represented in the model and the interactions between these groups, to give a coherent view of the contribution of protozoa to degradation of NDF in the rumen. Comparisons between predictions from the model and experimentally observed protozoal $\mathrm{OM}$ in the rumen showed general agreement for a range of dietary inputs. It was shown that, in general, increases in intake level reduced protozoal contribution, and substitution of roughages by concentrates increased protozoal contribution to NDF degradation in the rumen. These effects were further assessed by simulated changes in the chemical composition of the diets. The predicted protozoal contribution, as influenced by the diet, provided possible explanations for the differences in rumen NDF degradation observed when animals are defaunated.

\section{REFERENCES}

Amos, H. E. \& Akin, D. E. (1978). Rumen protozoal degradation of structurally intact forage tissues. Applied and Environmental Microbiology 36, 513-522.

Bibby, J. \& Toutenburg, H. (1977). Prediction and Improved Estimation in Linear Models. London: John Wiley \& Sons.

Bosch, M. W., Tamminga, S., Post, G., Leffering, C. P. \& Muylaert, J. M. (1992). Influence of stage of maturity of grass silages on digestion processes in dairy cows. 1. Composition, nylon bag degradation rates, fermentation characteristics, digestibility and intake. Livestock Production Science 32, $245-264$.

Brock, T. D. (1966). Principles of Microbial Ecology. Englewood Cliffs: Prentice-Hall.

Coleman, G. S. (1975). The interrelationship between rumen ciliate protozoa and bacteria. In Digestion and Metabolism in the Ruminant, pp. 149-164 [I. W. McDonald and A. C. I. Warner, editors]. Armidale: University of New England Publishing Unit.

Coleman, G. S. (1986a). The metabolism of rumen ciliate protozoa. FEMS Microbiological Reviews 39, $321-344$.

Coleman, G. S. $(1986 \mathrm{~b})$. The distribution of carboxylmethylcellulase between fractions taken from the rumens of sheep containing no protozoa or one of five different protozoal populations. Journal of Agricultural Science, Cambridge 106, 121-127.

Coleman, G. S. (1988). The importance of rumen ciliate protozoa in the growth and metabolism of the host ruminant. International Journal of Animal Sciences 3, 75-95.

Coleman, G. S. (1989). Protozoal-bacterial interactions in the rumen. In The Roles of Protozoa and Fungi in Ruminant Digestion, pp. 13-27 [J. V. Nolan, R. A. Leng and D. I. Demeyer, editors]. Armidale: Penambul Books.

Coleman, G. S. (1992). The rate of uptake and metabolism of starch grains and cellulose particles by Entodinium 
species, Eudiplodinium maggii, some other entodiniomorphid protozoa and natural protozoal populations taken from the ovine rumen. Journal of Applied Bacteriology 73, 507-513.

Demeyer, D. I. (1981). Rumen microbes and digestion of plant cell walls. Agriculture and Environment 6, $295-337$.

Demeyer, D. I. (1989). Effect of defaunation on rumen fibre digestion and digesta kinetics. In The Roles of Protozoa and Fungi in Ruminant Digestion, pp. 171-179 [J. V. Nolan, R. A. Leng and D. I. Demeyer, editors]. Armidale: Penambul Books.

Dijkstra, J. (1994). Simulation of the dynamics of protozoa in the rumen. British Journal of Nutrition 72, 679-699.

Dijkstra, J., Neal, H. D. St C., Beever, D. E. \& France, J. (1992). Simulation of nutrient digestion, absorption and outflow in the rumen: model description. Journal of Nutrition 122, 2239-2256.

Dijkstra, J., Neal, H. D. St C., Beever, D. E., Gill, M. \& France, J. (1990). Representation of microbial metabolism in a mathematical model of rumen fermentation. In Proceedings of the Third International Workshop on Modelling Digestion and Metabolism in Farm Animals, pp. 47-63 [A. B. Robson and D. P. Poppi, editors]. Lincoln: Lincoln University Press.

France, J. \& Thornley, J. H. M. (1984). Mathematical Models in Agriculture, p. 24. London: Butterworths.

Gijzen, H. J., Lubberding, H. L., Gerhardus, M. J. T. \& Vogels, G. D. (1988). Contribution of rumen protozoa to fibre degradation and cellulase activity in vitro. FEMS Microbiological Ecology 53, 35-44.

Gill, M., Beever, D. E. \& France, J. (1989). Biochemical bases needed for the mathematical representation of whole animal metabolism. Nutrition Research Reviews 2, 181-200.

Grenet, E., Breton, A., Barry, P. \& Fonty, G. (1989). Rumen anaerobic fungi and plant substrates colonization as affected by diet composition. Animal Feed Science and Technology 26, 55-70.

Hidayat, Hillman, K., Newbold, C. J. \& Stewart, C. S. (1993). The contributions of bacteria and protozoa to ruminal forage fermentation in vitro, as determined by microbial gas production. Animal Feed Science and Technology 42, 193-208.

Hsu, J. T., Fahey, G. C. Jr, Clark, J. H., Berger, L. L. \& Merchen, N. R. (1991). Effects of urea and sodium bicarbonate supplements of a high-fiber diet on nutrient digestion and ruminal characteristics of defaunated sheep. Journal of Animal Science 69, 1300-1311.

Hume, I. D., Moir, R. J. \& Somers, M. (1970). Synthesis of microbial protein in the rumen. I. Infiuence of the level of N-intake. Australian Journal of Agricultural Research 21, 283-296.

Hungate, R. E. (1975). The rumen microbial ecosystem. Annual Review in Ecological Systems 6, 39-66.

Jouany, J. P. (1989). Effects of diet on populations of rumen protozoa in relation to fibre digestion. In The Roles of Protozoa and Fungi in Ruminant Digestion, pp. 59-74. [J. V. Nolan, R. A. Leng and D. I. Demeyer, editors] Armidale : Penambul Books.

Jouany, J. P., Demeyer, D. I. \& Grain, J. (1988). Effect of defaunating the rumen. Animal Feed Science and Technology 21, 229-265.

Kayouli, C., Demeyer, D. I., Van Nevel, C. J. \& Dendooven, R. (1984). Effect of defaunation on straw digestion in sacco and on particle retention in the rumen. Animal Feed Science and Technology 10, 165-172.

Kayouli, C., Van Nevel, C. J., Dendooven, R. \& Demeyer, D. I. (1986). Effect of defaunation and refaunation of the rumen on rumen fermentation and N-flow in the duodenum of sheep. Archives of Animal Nutrition 36, $827-837$.

Krebs, G. A., Leng, R. A. \& Nolan, J. V. (1989). Microbial biomass and production rates in the rumen of faunated and fauna-free sheep on low protein fibrous feeds with or without nitrogen supplementation. In The Roles of Protozoa and Fungi in Ruminant Digestion, pp. 295-299 [J. V. Nolan, R. A. Leng and D. I. Demeyer, editors]. Armidale: Penambul Books.

Kurihara, Y., Takechi, T. \& Shibata, F. (1978). Relationship between bacteria and ciliate protozoa in the rumen of sheep fed a purified diet. Journal of Agricultural Science, Cambridge 90, 373-381.

Latham, M. J., Sharpe, E. \& Sutton, J. D. (1971). The microbial flora of the rumen of cows fed hay and high cereal rations and its relationship to rumen fermentation. Journal of Applied Bacteriology 34, 425-434.

Leng, R. A. (1982). Dynamics of protozoa in the rumen of sheep. British Journal of Nutrition 48, $399-415$.

Leng, R. A., Nolan, J. V., Cumming, G., Edwards, S. R. \& Graham, C. A. (1984). The effects of monensin on the pool size and turnover rate of protozoa in the rumen of sheep. Journal of Agricultural Science, Cambridge 102 , 609613

McCarthy, R. D. Jr, Klusmeyer, T. H., Vicini, J. L., Clark, J. H. \& Nelson, D. R. (1989). Effects of source of protein and carbohydrate on ruminal fermentation and passage of nutrients to the small intestine of lactating cows. Journal of Dairy Science 72, 2002-2016.

Mehrez, A. Z., Ørskov, E. R. \& McDonald, I. (1977). Rates of rumen fermentation in relation to ammonia concentration. British Journal of Nutrition 38, 437-443.

Mitchell, E. L. \& Gauthier, J. (1981). Advanced Continuous Simulation Language. User Guide/Reference Manual, 3rd ed. Concord: Mitchell and Gauthier Ass.

Nagaraja, T. G., Towne, G. \& Beharka, A. A. (1992). Moderation of ruminal fermentation by ciliated protozoa in cattle fed a high-grain diet. Applied and Environmental Microbiology 58, 2410-2414.

Neal, H. D. St C., Dijkstra, J. \& Gill, M. (1992). Simulation of nutrient digestion, absorption and outflow in the rumen: model evaluation. Journal of Nutrition 122, 2257-2272.

Newbold, C. J., Griffin, P. W. \& Wallace, R. J. (1989). Interaction between rumen bacteria and ciliate protozoa in their attachment to barley straw. Letters in Applied Microbiology 8, 63-66. 
Newbold, C. J. \& Hillman, K. (1990). The effect of ciliate protozoa on the turnover of bacterial and fungal protein in the rumen of sheep. Letters in Applied Microbiology 11, 100-102.

Orpin, C. G. \& Letcher, A. J. (1984). Effect of absence of ciliate protozoa on rumen fluid volume, flow rate and bacterial populations in sheep. Animal Feed Science and Technology 10, 145-153.

Owens, F. N. \& Goetsch, A. L. (1986). Digesta passage and microbial protein synthesis. In Control of Digestion and Metabolism in Ruminants, pp. 196-223 [L. P. Milligan, W. L. Grovum and A. Dobson, editors]. Englewood Cliffs: Prentice-Hall.

Pirt, S. J. (1965). The maintenance energy of bacteria in growing cultures. Proceedings of the Royal Society London, Series B. 163, 224-231.

Prins, R. A. \& Van Hoven, W. (1977). Carbohydrate fermentation by the rumen ciliate Isotricha prostoma. Protistologica 13, 549-556.

Punia, B. S., Leibholz, J. \& Faichney, G. J. (1987). The role of rumen protozoa in the utilization of paspalum (Paspalum dilatatum) hay by cattle. British Journal of Nutrition 57, 395-406.

Robinson, P. H., Tamminga, S. \& Van Vuuren, A. M. (1986). Influence of declining level of feed intake and varying the proportion of starch in the concentrate on rumen fermentation in dairy cows. Livestock Production Science 15, 173-189.

Robinson, P. H., Tamminga, S. \& Van Vuuren, A. M. (1987). Influence of declining level of feed intake and varying the proportion of starch in the concentrate on rumen ingesta quantity, composition and kinetics of ingesta turnover in dairy cows. Livestock Production Science 17, 37-62.

Romulo, B., Bird, S. H. \& Leng, R. A. (1989). Effects of defaunation and protein supplementation on intake, digestibility, $\mathrm{N}$ retention, and fungal numbers in sheep fed straw-based diets. In The Roles of Protozoa and Fungi in Ruminant Digestion, pp. 285-288 [J. V. Nolan, R. A. Leng and D. I. Demeyer, editors]. Armidale: Penambul Books.

Russell, J. B. \& Dombrowski, D. B. (1980). Effect of pH on the efficiency of growth by pure cultures of rumen bacteria in continuous culture. Applied and Environmental Microbiology 39, 604-610.

Tamminga, S. (1981). Nitrogen and amino acid metabolism in dairy cows. PhD Thesis, Wageningen Agricultural University.

Thornley, J. H. M. \& Johnson, I. R. (1990). Plant and Crop Modelling. A Mathematical Approach to Plant and Crop Physiology. Oxford: Clarendon Press.

Towne, G., Nagaraja, T. G., Brandt, R. T. Jr \& Kemp, K. (1990). Ruminal ciliated protozoa in cattle fed finishing diets with or without supplemental fat. Journal of Animal Science 68, 2150-2155.

Trinci, A. P. J., Davies, D. R., Gull, K., Lawrence, M. I., Nielsen, B. B., Rickers, A. \& Theodorou, M. K. (1994). Anaerobic fungi in herbivorous animals. Mycological Research 98, 129-152.

Ushida, K. \& Jouany, J. P. (1990). Effect of defaunation on fibre digestion in sheep given two isonitrogenous diets. Animal Feed Science and Technology 29, 153-158.

Ushida, K., Jouany, J. P. \& Demeyer, D. I. (1991). Effects of presence or absence of rumen protozoa on the efficiency of utilization of concentrate and fibrous feeds. In Physiological Aspects of Digestion and Metabolism in Ruminants: Proceedings of the 7th International Symposium on Ruminant Physiology, pp. 625 654 [T. Tsuda, Y. Sasaki and R. Kawashima, editors]. San Diego: Academic Press.

Ushida, K., Jouany, J. P. \& Thivend, P. (1986). Role of rumen protozoa in nitrogen digestion in sheep given two isonitrogenous diets. British Journal of Nutrition 56, 407-419.

Ushida, K., Kayouli, C., De Smet, S. \& Jouany, J. P. (1990). Effect of defaunation on protein and fibre digestion in sheep fed on ammonia-treated straw-based diets with or without maize. British Journal of Nutrition 64, $765-775$

Van Gylswyck, N. O. \& Labuschagne, J. P. L. (1971). Relative efficiency of pure cultures of different species of cellulolytic rumen bacteria in solubilizing cellulose in vitro. Journal of General Microbiology 66, $109-113$.

Van Hoven, W. \& Prins, R. A. (1977). Carbohydrate fermentation by the rumen ciliate Dasytricha ruminantium. Protistologica 13, 599-606.

Van Soest, P. J. (1982). Nutritional Ecology of the Ruminant. Corvallis: O \& B Books.

Veira, D. M., Ivan, M. \& Jui, P. Y. (1983). Rumen ciliate protozoa: effects on digestion in the stomach of sheep Journal of Dairy Science 66, $1015-1022$.

Williams, A. G. (1986). Rumen holotrich protozoa. Microbiological Reviews 50, $25-49$.

Williams, A. G. \& Coleman, G. S. (1988). The rumen protozoa. In The Rumen Microbial Ecosystem, pp. 77 -128 [P. N. Hobson, editor]. London: Elsevier Science Publishers.

Williams, A. G. \& Withers, S. E. (1991). Effect of ciliate protozoa on the activity of polysaccharide-degrading enzymes and fibre breakdown in the rumen ecosystem. Journal of Applied Bacteriology 70, 144-155.

Yoder, R. D., Trenkle, A. \& Burroughs, W. (1966). Influence of rumen protozoa and bacteria upon cellulose digestion in vitro. Journal of Animal Science 25, 609-612. 